\title{
Anti-aging effects of Muntingia calabura leaves extract in D-galactose-induced skin aging mouse model
}

\author{
Evy Sulistyoningrum ${ }^{1 *}$, Rosmelia Rosmelia², Muthmainnah K. Hamid ${ }^{3}$, Wulan Sari Tias Nuraini ${ }^{3}$ \\ ${ }^{1}$ Histology Department, Faculty of Medicine, Universitas Islam Indonesia, Yogyakarta, Indonesia. \\ ${ }^{2}$ Department of Dermatology and Venereology, aculty of Medicine, Universitas Islam Indonesia, Yogyakarta, Indonesia. \\ ${ }^{3}$ Faculty of Medicine, Universitas Islam Indonesia, Yogyakarta, Indonesia.
}

\begin{tabular}{|c|c|}
\hline ARTICLE INFO & ABSTRACT \\
\hline Received on: 21/01/2019 & Glycation and production of free radicals become important mechanisms underlying skin aging. Muntingia calabura \\
\hline Accepted on: $24 / 06 / 2019$ & is reported to have antioxidant activity in many studies. The effects of $M$. calabura aqueous leaves extract (MCALE) \\
\hline Available online: 01/09/2019 & $\begin{array}{l}\text { on oxidative stress and histological changes of mouse model of skin aging were evaluated in this research. Twenty } \\
\text { male albino mice were divided into five groups: healthy control; aging control; aging + MCALE } 35 \mathrm{mg} / \mathrm{kg} \text {; aging + }\end{array}$ \\
\hline $\begin{array}{l}\text { Key words: } \\
\text { Muntingia calabura, } \\
\text { malondealdehyde, skin aging, } \\
\text { dermal fibroblast, dermal } \\
\text { collagen, D-galactose. }\end{array}$ & $\begin{array}{l}\text { MCALE } 70 \mathrm{mg} / \mathrm{kg} \text {; and aging+vitamin C } 28 \mathrm{mg} / \mathrm{kg} \text {. To induce aging condition, oral gavage of D-galactose } 500 \mathrm{mg} / \\
\mathrm{kg} / \mathrm{day} \text { were given for } 6 \text { weeks. Prior to treatment, blood samples were taken for malondealdehyde (MDA) analyses. } \\
\text { MCALE and vitamin C were administered subsequently by oral gavage for } 4 \text { weeks and at the end, MDA analyses } \\
\text { were performed again. Routine and van Gieson's staining were performed to analyze epidermal thickness, fibroblast } \\
\text { cell, and density of dermal collagen. Groups received MCALE } 70 \mathrm{mg} / \mathrm{kg} \text { and vitamin C had lower plasma MDA } \\
\text { level; higher fibroblast number and density of collagen bundles which is reduced in the aging group }(p<0.05) \text {. } \\
\text { However, epidermal thickness among the five groups was not significantly different. It was concluded that MCALE } \\
\text { had antioxidant and anti-aging effects on D-galactose-induced mouse model of skin aging. }\end{array}$ \\
\hline
\end{tabular}

\section{INTRODUCTION}

Aging is a natural process which occurred since the beginning of life. Chronological aging and photo aging can contribute to result in skin aging. Aging induces changes in the skin morphological structure, skin integrity, and alters normal function of skin. Aging not only affected epidermis, resulted in thinner epidermis, but also affected dermis. Dermal matrix was degraded and cellular synthesis' capability decreased (Pageon et al., 2014). Aged skin develop dermal atrophy and decreased fibroblast activities (Tigges et al., 2014) resulting in declined elasticity, uneven pigmentation, increased roughness and dryness (Waqas et al., 2014), and also fine rhytids which can be followed by persistent deeper folds (Zhang et al., 2014).

\footnotetext{
"Corresponding Author

Evy Sulistyoningrum, Histology Department, Faculty of Medicine,

Universitas Islam Indonesia, Yogyakarta, Indonesia.

E-mail: evy.sulistyoningrum@uii.ac.id
}

Many theories have been postulated to explain aging mechanism, including increased production of free radicals and the macromolecular cross-linking due to glycation reaction (Zhang et al., 2014). When free amine groups non-enzymatically reacted with reducing sugars, Advanced Glycation End-products (AGEs) will be producted (Asif et al., 2000). This reaction is called Maillard reaction or glycation. AGEs can cause macromolecular cross-linking, which commonly occured in tissues with slow degraded macromolecules, for example, skin collagen in dermal extracellular matrix (Frye et al., 1998). Accumulation of AGEs in matrix of aged skin will further impair skin homeostasis. This impairment is characterized by senescence cell viability, alteration in gene expression, and also in global synthesis. Eventually, these cumulative alterations will affect biomechanic properties of the skin (Pageon et al., 2014).

D-galactose aging animal model is one of wellrecognized animal models for aging condition and has been widely used in anti-aging research (Ho et al., 2003). Many studies have shown that D-galactose-induced condition mimetic aging in experimental animals (Song et al., 1999). Compared with 
other animal aging models, such as senescence-accelerated mouse model and natural aging mode, the modelling method of D-gal animal model is simple, inexpensive, and stable (Ho et al., 2003). Animal received D-galactose will gain an increase of intracellular galactose concentration. Galactose then be reduced into galactitol in the catalysis of aldose reductase. Galacticol will be accumulated in the cell, since it cannot be metabolized. Intracellular accumulation of galacticol will change the cellular osmotic pressure that leads to cell swelling and dysfunction and ultimately leads to aging (Chen et al., 2010). In addition, free radicals generated from D-gal metabolism in vivo can result in aging as well (Li et al., 2012).

There are many intrinsic antioxidants which can be used to protect skin damages due to free radicals, but sometimes body needs extrinsic antioxidants. Recent studies reported antioxidant and anti-aging effect of some natural products, such as Muntingia calabura or Jamaican cherry (Ramadas et al., 2015). Muntingia calabura is an evergreen tree originally distributed in tropical America, but now it is widely distributed throughout the world. Not only nutritional values, but $M$. calabura also have been reported to have medicinal uses. Scientifically, a number of flavonoids and phenolic compounds have been isolated from various part of the plant and structures were elucidated by spectroscopic analysis. The leaves of $M$. calabura have potential antibacterial effect in vitro against certain bacteria (Zakaria et al., 2006), antipyretic and anti-inflammatory effect in vivo (Zakaria et al., 2007), free radical scavenging activity (Bodke et al., 2013; Ramadas et al., 2015), and also antinociceptive activity (Zakaria et al., 2014). Among other plant body parts, leaves of M. calabura had the highest antioxidant properties (Ramadas et al., 2015). It is reported that leaves extract of $M$. calabura contain many phytoconstituents, such as saponins, polyphenols, ascorbic acid, tannins, flavonoids, and also $\alpha$-tocopherol (Premakumari et al., 2010). In the present study, anti-aging and antioxidant effects of M. calabura aqueous leaves extract in D-gal-induced skin aging mouse model were examined.

\section{MATERIALS AND METHODS}

We conducted an experimental study in the Integrated Research Laboratory, Faculty of Medicine, Universitas Islam Indonesia, Yogyakarta, Indonesia from December 2016 to June 2017.

\section{Extract preparation}

Young leaves of $M$. calabura were collected from the Universitas Islam Indonesia campus during December 2016. Plant's speciment was authenticated by Faculty of Mathematics and Natural Sciences, Universitas Islam Indonesia, Yogyakarta, Indonesia. The collected leaves were cleaned with tap water and air-dried for 1 week. The leaves were then dried in $50 \pm 1^{\circ} \mathrm{C}$ and then ground using a milling machine into powder. About $1,000 \mathrm{~g}$ of the powder was soaked with 51 of distilled water for 24 hours and then filtered using filter paper. Residue was re-soaked with 5 1 of distilled water for the next $2 \times 24$ hours. All filtrates from $3 \times$ 24 hours extraction were collected and solvents were removed by rotary evaporation to obtain crude extract. Crude extract was stored in $4^{\circ} \mathrm{C}$ until use. Aliquots were withdrawn and then dissolved with distilled water to obtain the desired doses.

\section{Experimental animals and intervention}

We used 20 healthy male mice (Mus musculus Balb/C) 12 weeks old age $(25 \pm 5 \mathrm{~g})$. The number of the animals was estimated based on Festing research equation (Charan and Khantaria, 2013). Mice were housed in a group cages in standard laboratory condition $\left(22-30^{\circ} \mathrm{C}\right.$ room temperature, and 12 hours light/dark cycle) in the Integrated Research Laboratory. Mice were acclimatized for 7 days before experiment. During acclimatization and experiment animals were given standard pellet diet and mineral water ad libitum.

\section{Design of experiment}

Experimental animals were divided into five intervention groups: Group I is normal control group (only received distilled water during study); aging control group received distilled water (Group II); aging + MCALE (M. calabura aqueous leaves extract) $35 \mathrm{mg} / \mathrm{kg}$ (Group III), and aging + MCALE $70 \mathrm{mg} / \mathrm{kg}$ (Group IV); and aging + vitamin C $28 \mathrm{mg} / \mathrm{kg}$ (Group V). To induce aging condition, group II-V were force fed with D-galactose (SigmaAldrich, USA) $500 \mathrm{mg} / \mathrm{kg}$ daily for 6 weeks. Pre-treatment, malondealdehyde (MDA) level was analyzed from blood samples taken from retro-orbital plexus under light anaesthesia. To obtain treatment solution, crude extract and vitamin C (Dexa Medica, Indonesia) were weighted using electronic balance (Ohauss PA214, USA) and reconstituted in distilled water. Animals received $1 \mathrm{ml}$ working solution orally for 4 weeks. After 4 weeks of treatment, animals were anesthesized with ketamin injection (i.m) and blood samples were taken from retro-orbital plexus, after which animals were sacrificed. The dorsal skin of the animals was shaved and an area of $1 \times 1 \mathrm{~cm}^{2}$ was taken for histology staining.

\section{Plasma malondealdehyde analysis}

Blood was collected from retro-orbital plexus and maintained on ice in tubes containing anticoagulant followed by centrifugation at 4,000 rpm for 15 minutes. Plasma was pipetted and stored for $-20^{\circ} \mathrm{C}$ for later analysis. Plasma MDA levels were determined based on Ohkawa's procedure using (TBA) thiobarbituric acid (Sudha et al., 2012). Standard MDA solution was processed along with test samples. $0.8 \%$ of TBA acid was added to sample, then $8.1 \%$ sodium dodecyl sulfate and acetic acid were added and then mixed well. After heated at $95^{\circ} \mathrm{C}$ for 1 hour, all mixtures then cooled under tap water and then absorbance was measured at $532 \mathrm{~nm}$ to estimate plasma MDA. Plasma MDA level was expressed in $\mathrm{nmol} / \mathrm{ml}$.

\section{Microscopic analysis}

Dorsal skin tissue was placed in $10 \%$ buffer formalin, cast in paraffin. Five-millimeter paraffin sections were deparaffinized, stained for Hematoxylin-Eosin to evaluate dermal fibroblast and epidermal thickness, and also stained for van Gieson's (picric acid and acis fuchsin mixture) to quantify density of dermal collagen bundles. Photomicrograph was taken with Olympus CX22 (Olympus, Japan) equipped with Optilab Viewer (Miconos, Indonesia). Dermal fibroblast counting was performed in five separated fields, while thickness of epidermis was measured as the distance from basal membrane of epidermis to the uppermost corneal layer employing Image Raster (Miconos, Indonesia) also in five separate fields. To perform morphometric 
analysis for density of dermal collagen bundles, papillary dermis' area occupied by collagen bundles (characterized with red-colored bundles) was compared with total area and reported as percentage. This analysis performed using 400× magnification, with Image $\mathrm{J}$ software (Maryland, USA), in five fields of each sample.

\section{Ethical clearance}

Research protocol was approved by the Health Research Ethics Committee, Faculty of Medicine, Universitas Islam Indonesia (Registration number 32/Ka.Kom.Et/70/KE/I/2016).

\section{Statistical analysis}

All the analyses were performed with IBM SPSS Statistics version 21. Normal data were reported as mean $\pm \mathrm{SD}$; One way ANOVA was used to compared inter-group comparison and Tukey HSD post-hoc test for multiple comparisons. $p$ value $<0.05$ was considered as significant.

\section{RESULTS AND DISCUSSION}

Research for investigating anti-aging and antioxidant effect of M. calabura leaves extract on D-galactose-induced skin aging mouse model was conducted for 12 weeks. During aging induction and interventions, animals were in good condition, there is no sign of appetite abnormalities, abnormal discharges, while volume of feces and urine were reported normal. Induction of aging with oral gavage of D-gal for 6 weeks significantly elevated plasma MDA level compared with normal control groups (Table 1). Induction of D-gal $500 \mathrm{mg} / \mathrm{kg}$ orally for 6 weeks can increase plasma level of MDA, as one of the senescence-associated markers. This research is consistent with Yang et al. (2012) which also reported that plasma MDA level were increased in mice received D-galactose administration for 6 weeks. Wherever reactive oxygen species (ROS) are generated, intracellular oxidant levels will increased and will lead to two main effects: damage in several cellular components and activation of specific signalling pathways. These two main effects can affect significantly on physiological processes and metabolic pathway closely bounded up with aging of the skin. Excess ROS can make lipid peroxidated in vivo and the final oxidation product is MDA. Malondealdehyde can direct the protein and nucleic acid to cross-link and have cytotoxicity effect. Therefore, body's status of lipid peroxidation can be reflected directly by the content of MDA, while cellular damage level brought by ROS also can be indirectly reflected by the content of MDA (Jiang et al., 2013).

In order to mimic natural aging in experimental animals, chronic administration of D-gal has been used to induce oxidative stress in vivo. Cells can metabolize D-galactose at normal level, but when D-galactose was given at high doses, it will greatly increase the concentration of intracellular galactose in vivo. Intracellular $\mathrm{D}$-galactose can be converted by galactose oxidase into aldose and hydroperoxide. This reaction will generate oxygen-derived free radicals and superoxide anions (Wang et al., 2012). D-galactose can also reacted with free amino acids to form AGEs. These free radicals generated from D-gal metabolism in vivo can result in aging (Ye et al., 2014). Aging condition resulted from chronic D-galactose administration is one of the best aging models and mimics clinical aging studies (Parameshwaran et al., 2010). Aged animal induced by D-gal demonstrated neurological alteration, as well as reduced antioxidant enzymes' activities, and impaired immune responses similar with normal aged individuals. D-galactose-induced models are widely used as a reliable aging mouse model (Mohammadirad et al., 2013) and also suitable model for studying therapeutic antioxidant treatment (Parameshwaran et al., 2010).

After 4 weeks of treatment, aging group received vitamin $\mathrm{C}$ and MCALE $70 \mathrm{mg} / \mathrm{kg}$ had significant lower plasma MDA level compared with aging group, but when compared with normal group, it still had higher plasma MDA level (Fig. 1). Aging group also had the lowest dermal fibroblast cell number (Fig. 3), while group received treatment with MCALE and vitamin $C$ had higher dermal fibroblast cell number, but still had lower dermal fibroblast number than normal group. Normal group had the highest density of dermal collagen bundles, while aging group had lowest density

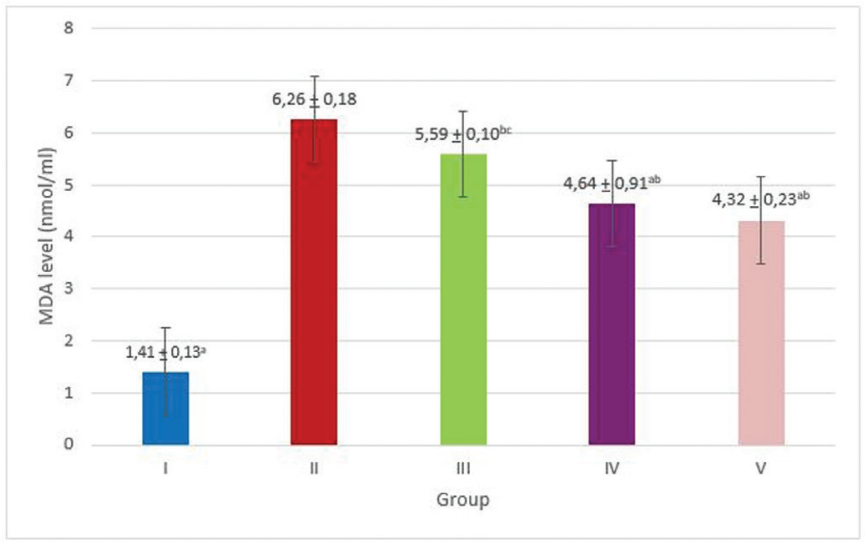

Figure 1. Post treatment plasma MDA level. Group I: normal control (receive only distilled water); Group II: aging control + distilled water, Group III: aging + MCALE $35 \mathrm{mg} / \mathrm{kg}$, Group IV: aging + MCALE $70 \mathrm{mg} / \mathrm{kg}$, Group V: aging + vitamin C $28 \mathrm{mg} / \mathrm{kg},{ }^{\mathrm{a}} p<0.05$ compared with Group II, ${ }^{\mathrm{b}} p<0.05$ compared with Group I, ${ }^{c} p<0.05$ compared with Group V (ANNOVA followed by post hoc LSD).

Table 1. Characteristic of subjects.

\begin{tabular}{ccccc}
\hline Group & $\boldsymbol{n}$ & $\begin{array}{c}\text { Weight prior intervention } \\
\text { (gram) }\end{array}$ & $\begin{array}{c}\text { Weight after intervention } \\
\text { (gram) }\end{array}$ & $\begin{array}{c}\text { Plasma MDA level prior to treatment } \\
\text { (nmol/ml) }\end{array}$ \\
\hline I & 4 & $26.10 \pm 3.47$ & $42.32 \pm 2.41$ & $1.75 \pm 0.11$ \\
II & 4 & $27.50 \pm 1.58$ & $39.53 \pm 1.19$ & $6.47 \pm 0.09^{*}$ \\
III & 4 & $26.77 \pm 2.04$ & $40.18 \pm 1.36$ & $6.33 \pm 0.09^{*}$ \\
IV & 4 & $27.73 \pm 1.80$ & $43.65 \pm 2.35$ & $6.29 \pm 0.10^{*}$ \\
V & 4 & $29.45 \pm 2.77$ & $41.45 \pm 1.17$ & $6.32 \pm 0.19^{*}$ \\
\hline
\end{tabular}

Group I: normal control (receive only distilled water); Group II: aging control + distilled water, Group III: aging + MCALE $35 \mathrm{mg} / \mathrm{kg}$, Group IV: aging + MCALE $70 \mathrm{mg} / \mathrm{kg}$, Group V: aging + vitamin C $28 \mathrm{mg} / \mathrm{kg}{ }^{*} p<0.05$ compared with Group I (ANNOVA followed by post hoc LSD). 
of dermal collagen bundles. Aging group received MCALE 70 $\mathrm{mg} / \mathrm{kg}$ and vitamin $\mathrm{C}$ showed improvement in density of dermal collagen bundles compared with untreated aging group $(p<0.05)$ but still had significant difference with normal group $(p<0.05$, Fig. 4). On the contrary, there was no difference in epidermal thickness among five groups ( $p>0.05$, Fig. 2 ).

On dermal compartment, aging group had the lowest number of fibroblast cell (Fig. 3b). Skin aging is influenced by the many factors that act mainly on the dermis, such as extracellular matrix and fibroblast. Since dermal fibroblast had long life span, they are vulnerable to damages due to accumulation of metabolism products and abnormal adaptation. In skin aging, there's a declining of fibroblast growth capacity which further can lead to alteration of its functions in collagen synthesis (Tigges et al., 2014).

Fibroblast aging often connected with declining of growth factor signalling abnormality, which affect mainly on major growth factor for fibroblast, Platelet-Derived Growth Factor (PDGF). This growth factor can bind to both PDGF- $\alpha$ and PDGF- $\beta$ receptors. Binding of ligand and receptors will activate signalling pathways, including mitogen-activated protein, Phosphatidylinositol-3 kinase/Akt, and Janus kinase. In aging process, those signalling pathways activities decreased which can lead to decreasing of fibroblast proliferation. Dermal fibroblast aging also can occur via various mechanisms such as DNA damage, telomere shortening, post-transcriptional pre-mRNA processing disruption, epigenetic alteration, and dysfunction and damage of mitochondria (Tigges et al., 2014). It is also reported that dermal fibroblast of aged people had lower capability to
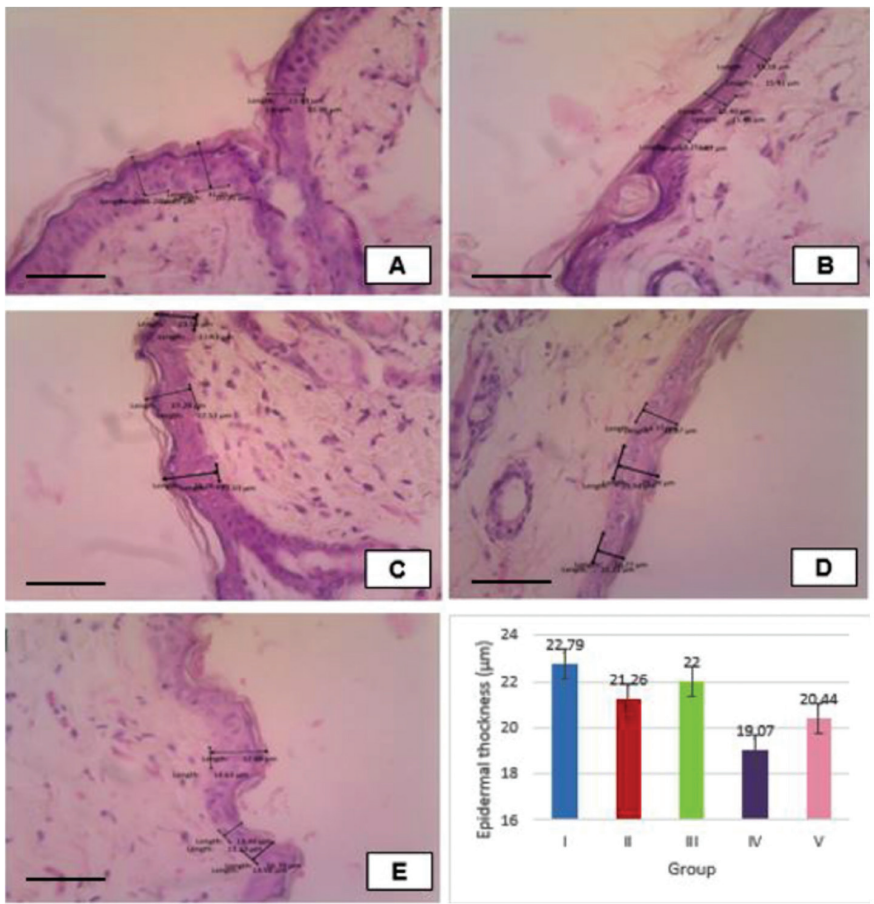

Figure 2. Higher magnification showed epidermal thickness of representative groups. $400 \times$ magnification, Routine staining. Bar represented $50 \mu \mathrm{m}$. Group I: normal control (receive only distilled water); Group II: aging control + distilled water, Group III: aging + MCALE $35 \mathrm{mg} / \mathrm{kg}$, Group IV: aging + MCALE 70 $\mathrm{mg} / \mathrm{kg}$, Group V: aging + vitamin C $28 \mathrm{mg} / \mathrm{kg}$.
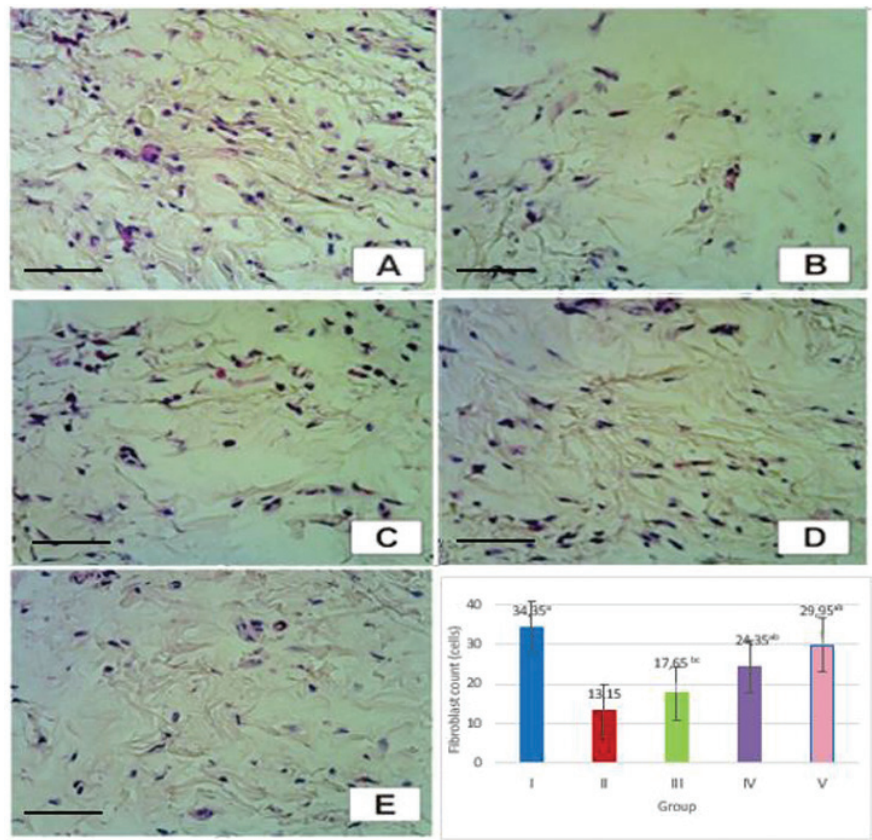

Figure 3. Higher magnification showed dermal fibroblast of representative groups. $400 \times$ magnification, Routine staining. Bar represented $50 \mu \mathrm{m}$. Group I: normal control (receive only distilled water); Group II: aging control + distilled water, Group III: aging + MCALE $35 \mathrm{mg} / \mathrm{kg}$, Group IV: aging + MCALE $70 \mathrm{mg}$ $\mathrm{kg}$, Group V: aging + vitamin C $28 \mathrm{mg} / \mathrm{kg}$, ${ }^{\mathrm{a}} p<0.05$ compared with Group II, ${ }^{\mathrm{b}} p<0.05$ compared with Group I, ${ }^{\mathrm{c}} p<0.05$ compared with Group V (ANNOVA followed by post hoc LSD).

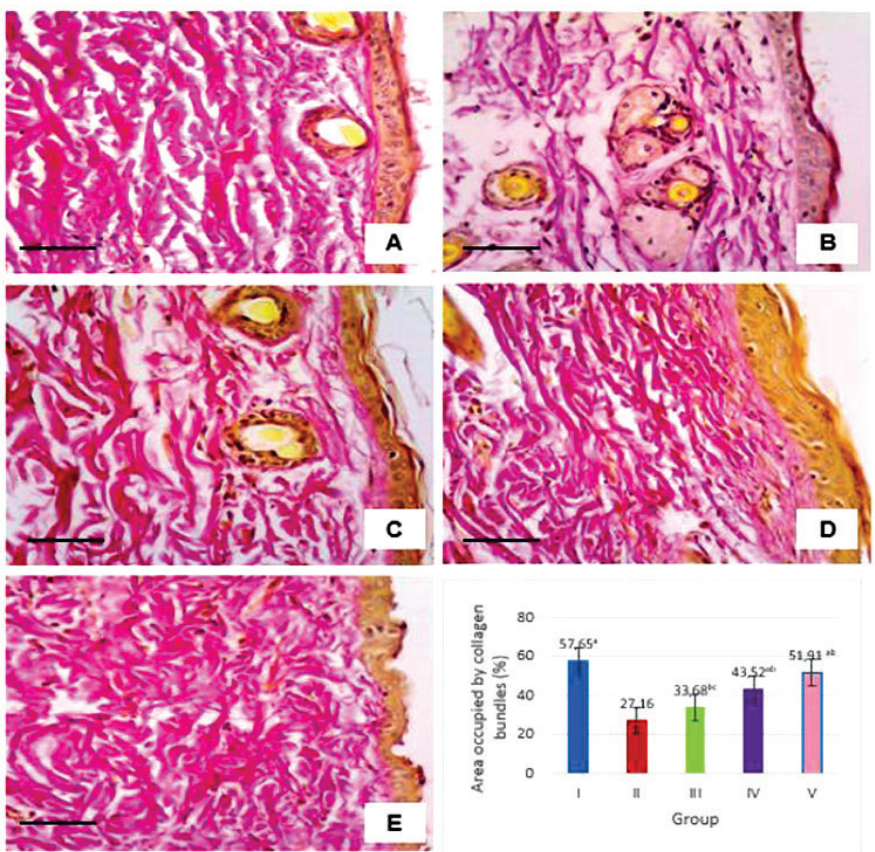

Figure 4. Higher magnification showed dermal collagen bundles (showed in red) of representative groups. $400 \times$ magnification, van Gieson's staining. Bar represented $50 \mu \mathrm{m}$. Graphic showed area fraction occupied by collagen bundles (\%). Group I: normal control (receive only distilled water); Group II: aging control + distilled water, Group III: aging + MCALE $35 \mathrm{mg} / \mathrm{kg}$, Group IV: aging + MCALE $70 \mathrm{mg} / \mathrm{kg}$, Group V: aging + vitamin C $28 \mathrm{mg} / \mathrm{kg},{ }^{\mathrm{a}} p<0.05$ compared with Group IIs, ${ }^{b} p<0.05$ compared with Group I, ${ }^{c} p<0.05$ compared with Group V (ANNOVA followed by post hoc LSD. 
replicate and had abnormal pattern of collagen and substance secretion (Marcos-Garcés et al., 2014).

Aging group also had the lowest density of collagen bundles (Fig. 4b). In aging condition, it has been reported that modified protein were accumulated due to post-translational nonenzymatic reactions, e.g., glycation and oxidation. This reaction produced AGEs which have catabolic effects on the molecules they bind (Marcos-Garcés et al., 2014). AGEs can cause protein cross-linking and polymerization. This modification, especially occured in long half-life proteins, such as dermal collagen (Odetti et al., 1998) which had 15 years half-life. AGE-modified collagen has abnormal characteristics, solubility, conformation, reactivity and also had very slow turnover rate due to its altered structure (Nedić et al., 2013). One of glycation products is pentosidine although only produced in a small fraction, it is considered to be a marker to evaluate biochemical changes following posttranslational reactions in aging tissues since its ability to cross-link the proteins (Odetti et al., 1998).

During skin aging, there was a loss density of collagen bundles due to declined activities of dermal fibroblast. Varani et al. (2006) reported this declining can lead to rapid decrease in collagen secretion, mainly type I and III, reduced synthesis of type I procollagen and reduced fibroblast proliferation. Dermal fibroblast decreased expression of growth factor essential for collagen homeostasis, such as Transforming Growth Factors (TGF)- $\beta$ and Connective Tissue Growth Factors (Quan et al., 2010). It is also reported that AGEs accumulation alters collagen conformation and produced more fragmented collagen bundles in aged dermis (Baroni et al., 2012). Decrease in collagen density is also reported to be connected with an increased expression of Matrix Metalloproteinases (MMPs) which can degrade extracellular matrix, such as MMP-1, MMP-2, and MMP-9 (Quan et al., 2011) promoted by fragmented collagen in the tissue (Hernández-Pérez and Mahalingam, 2012).

Treatment with vitamin $\mathrm{C}$ reduced plasma MDA level, indicated that MCALE and vitamin $\mathrm{C}$ had in vivo antioxidant property. Vitamin $\mathrm{C}$ is very important for skin health, it stimulates collagen production in the skin fibroblasts (Waqas et al., 2014). Vitamin $\mathrm{C}$ acts as a potent reductor, preventing damage due to free radical production during metabolism. Vitamin $\mathrm{C}$ also had cytoprotective effect, minimalize oxidation effect of the DNA, showed protection on lipid peroxidation, and able to restore oxidated amino acid to maintain protein integrity (Grosso et al., 2013). Vitamin $\mathrm{C}$ is an important antioxidant since it has capability to penetrate in deep skin due to their small molecular size. It has been reported that in 5\%-15\% concentration, vitamin $\mathrm{C}$ can attenuate skin aging, induce collagen production, including type I and type III collagen and also induce production of enzymes essential for collagen synthesis. Vitamin $\mathrm{C}$ is also had been reported to inhibit MMP-1 and collagenase-1, enzymes which is well known to have collagen degradation activity (Ganceviciene et al., 2012).

Treatment with MCALE $70 \mathrm{mg} / \mathrm{kg}$ gave positive effect on skin structural damage indicated by improved fibroblast cell count and density of dermal collagen bundles compared with untreated aging group. Phytochemical analyses of $M$. calabura leaves extracts demonstrated the presence of high content of phenolic compounds (Zakaria et al., 2011) and high total phenolic content value (Bodke et al., 2013). The antioxidant potential of $M$. calabura can be explained based on the respective phytoconstituents detected in the extract. The leaves extracts of $M$ calabura contained flavonoids, chlorophylls, and also ascorbic acid which had antioxidant activity. In vitro analyses showed that extracts of $M$. calabura (leaves, fruits, and roots) had good antioxidant activity when compared with common antioxidant substances (such as curcumin, $\alpha$-tocopherol, and ascorbic acid), and leaves extract of $M$ calabura had the highest antioxidant activity compared with other parts of the plants (Ramadas et al., 2015).

Tapas et al. (2008) had been shown that flavonoids to exert antioxidant, while others reported anti-inflammatory effect (Zakaria et al., 2007) and protective effect against paracetamolinduced hepatotoxicity (Mahmood et al., 2014). Moreover, Elekofehinti et al. (2012) demonstrated that saponins from Solanum anguivi fruits to have antioxidant and antiperoxidatives properties. Saponin had been reported to have anti-aging property, it can triggers activation of AKT/FOXO3a and Nrf2 pathways which further can enhance expression and function of antioxidant enzymes, such as superoxide dismutase- 2 and catalase (Ramadas et al., 2015). Muntingia calabura extracts also contain polyphenols which stabilize ROS via proton donation, hence prevent further lipid peroxidation (Balakrishnan et al., 2011). Polyphenols also had been reported to have anti-glycation activity via inhibition of RAGEs (Receptor for AGEs) signalling (Sadowska-Bartosz and Bartosz, 2015). Tannin have been reported to have in vitro radical scavenging activity, in vivo antioxidant activity via activation of antioxidant enzymes, and also possess anti-inflammatory activities as well (Kumari and Jain, 2012). Muntingia calabura leaves also contain ascorbic acid which can act as antioxidant and anti-aging agent (Ramadas et al. 2015) as well.

Although many positive results of $M$. calabura in improving skin histological parameters or aging, this research found no difference in epidermal thickness among the five groups. This research limited only measure it from histological section under light microscope. Although Lademann et al. (2007) reported there's no difference in measuring epidermal thickness via paraffine-block sections, laser scanning microscopy (LSM), and optical coherence tomography (OCT). Peña et al. (2014) suggested the use of LSM and OCT to avoid any damage and distortion of skin tissue during histological processes. More specific method will give specific and representative result on measuring epidermal thickness. Further investigation in safety of $M$. calabura is also needed to bring $M$. calabura study into clinical setting.

\section{CONCLUSION}

In brief, it can be concluded that $M$. calabura aqueous leaves extract in $70 \mathrm{mg} / \mathrm{kg}$ dose had anti-aging and antioxidant activity in vivo which characterized by plasma MDA level and fibroblast count and also the density of dermal collagen bundles. In the D-galactose-induced skin aging mouse model, plasma MDA level was increased and there was a decrease of fibroblast count and density of dermal collagen bundles. However, improvement of $M$. calabura leaves extract and vitamin $\mathrm{C}$ not yet give an equal result as the normal group. This result can be implemented in the future to promote the use of $M$. calabura aqueous leaves extracts as a complementary treatment for preventing skin aging. 


\section{ACKNOWLEDGMENTS}

This research was financially supported by grant from the Faculty of Medicine, Universitas Islam Indonesia year 2016. The authors would like to thank assistance of Mrs. Ernadita Budiasri during this research.

\section{CONFLICT OF INTEREST}

The authors declare that there are no conflicts of interest.

\section{REFERENCES}

Anandh T, Rajendran R. Evaluations of antioxidants and lipid peroxidation status among students. Int J Appl Biol Pharm Technol, 2012; 3(4):291-5.

Asif M, Egan J, Vasan S, Jyothirmayi GN, Masurekar MR, Lopez S, Williams C, Torres RL, Wagle D, Ulrich P, Cerami A, Brines M, Regan TJ. An advanced glycation end product cross-link breaker can reverse age-related increases in myocardial stiffness. Proc Natl Acad Sci USA, 2000; 97:2809-13.

Balakrishnan KP, Narayanaswamy N, Duraisamy A. Tyrosinase inhibition and anti-oxidant properties of Muntingia calabura extracts: in vitro studies. Int J Pharma Bio Sci, 2011; 2(1):B 294-303.

Baroni ER, Biondo-Simões M de LP, Auersvald A, Auersvald LA, Montemor NMR, Ortolan MC, Kohler JN. Influence of aging on the quality of the skin of white women: the role of collagen. Acta Cir Bras, 2012; 27(10):736-40.

Bodke YD, Aruna SM and Chandrashekar A. Antioxidant and in vivo anti-hyperglycemic activity of Muntingia calabura leaves extracts. Der Pharmacia Lettre, 2013; 5(3):427-35.

Charan J, Kantharia ND. How to calculate sample size in animal studies? J Pharmacol Pharmacother, 2013; 4(4):303-6.

Chen B, Zhong Y, Peng W, Sun Y, Kong W. Age-related changes in the central auditory system: comparison of D-galactose-induced aging rats and naturally aging rats. Brain Res, 2010; 1344:43-53.

Elekofehinti OO, Adanlawo IG, Komolafe K and Ejelonu OC. Saponins from Solanum anguivi fruits exhibit antioxidant potential in Wistar rats. Ann Biol Res, 2012; 3(7):3212-7.

Frye EB, Degenhardt TP, Thorpe SR, Baynes JW. Role of the Maillard reaction in aging of tissue proteins. Advanced glycation end product-dependent increase in imidazolium cross-links in human lens proteins. J Biol Chem, 1998; 273:18714-9.

Ganceviciene R, Liakou AI, Theodoridis A, Makrantonaki E, and Zouboulis CC. Skin anti-aging strategies. Dermatoendocrinology, 2012; 4(3):308-9.

Grosso G, Bei R, Mistretta A, Marventano S, Calabrese G, Masuelli L, Giganti MG, Modesti A, Galvano F, Gazzolo D. Effects of vitamin $\mathrm{C}$ on health: a review of evidence. Front Biosci, 2013; 18:1017-29.

Hernández-Pérez $\mathrm{M}$ and Mahalingam M. Matrix metalloproteinases in health and disease: insight from dermatopathology. Am J Dermatopathol, 2013; 34(6):565-79.

Ho S, Liu J, Wu R. Establishment of the mimetic aging effect in mice caused by D-galactose. Biogerontology, 2003; 4(1):15-8.

Jiang ZQ, Li Y, Jiang LH, Gu H, and Wang MY. Hepatoprotective effects of extracts from processed Corni fructus against D-galactoseinduced liver injury in mice. J Chin Med Mater, 2013; 36(1):85-9.

Kumari M, Jain S. Tannins: an antinutrient with positive effect to manage diabetes. Res J Recent Sci, 2012; 1(12):70-3.

Li Z, Liu R, Kang X and Wang X. Study on establishment of kidney deficient aging model and comparison with D-galactose induced aging model. China J Chinese Materia Med, 2012; 37(16):2435-8.

Lademann J, Otberg N, Richter H, Meyer L, Audring H, Teichmann A, Thomas S, Knüttel A, Sterry W. Application of optical non-invasive methods in skin physiology: a comparison of laser scanning microscopy and optical coherent tomography with histological analysis. Skin Res.Technol, 2007; 13(2):119-32.
Mahmood ND, Mamat SS, Kamisan FH, Yahya F, Kamarolzaman MFF, Nasir N, Mohtarrudin N, Tohid SF, Zakaria ZA. Amelioration of paracetamol-induced hepatotoxicity in rat by the administration of methanol extract of Muntingia calabura L. leaves. BioMed Res Int, 2014; 2014:695678; doi:10.1155/2014/695678

Marcos-Garcés V, Aguilar PM, Serrano CB, Bustos VG, Seguí JB, Izquierdo AF, Ruiz-Saurí A. Age-related dermal collagen changes during development, maturation, and ageing-a morphometric and comparative study. J Anat, 2014; 225(1):98-108.

Mohammadirad A, Aghamohammadali-Sarraf F, Badiei S, Faraji Z, Hajiaghaee R, Baeeri M, Gholami M, Abdollahi M. Anti aging effects of some selected Iranian folk medicinal herbs-biochemical evidences. Iran J Basic Med Sci, 2013; 16(11):1170-80.

Nedić O, Rattan SIS, Grune T, Trougakos IP. Molecular effects of advanced glycation end products on cell signalling pathways, ageing and pathophysiology. Free Radic Res, 2013; 47(Suppl. 1):28-38.

Odetti P, Aragno I, Garibaldi S, Valentini S, Pronzato MA, Rolandi R. Role of advanced glycation end products in aging collagen. A scanning force microscope study. Gerontology, 1998; 44(4):187-91.

Pageon, H., Zucchi, H, Rousset F, Monnier VM, Asselineau D. Skin aging by glycation: lessons from the reconstructed skin model. Clin Chem Lab Med. 2014; 52(1):169-74.

Parameshwaran K, Irwin MH, Steliou K, and Pinkert CA. $\mathrm{D}$-galactose effectiveness in modeling aging and therapeutic antioxidan treatment in mice. Rejuvenation Res, 2010; 13(6):729-35.

Peña A, Arronte M, Posada ED, Ponce L, Flores T. Non-invasive optical method for epidermal thickness estimation. Online J Biol Sci, 2014; 14(2):163-6.

Premakumari KB, Siddiqua A, Sultana R, Vithya, Savitha Antioxidant activity and estimation of total phenolic content of Muntingia calabura by colorimetry. Int J ChemTech Res, 2010; 2(1):205-8.

Quan T, Qin Z, Robichaud P, Voorhees JJ, Fisher GJ. CCN1 contributes to skin connective tissue aging by inducing age-associated secretory phenotype in human skin dermal fibroblast. J Cell Commun Signal, 2011; 5(3):201-7.

Quan T. Shao Y, He T, Voorhees JJ, Fisher GJ. Reduced expression of connective tissue growth factor (CTGF/CCN2) mediates collagen loss in chronologically aged human skin. J Invest Dermatol, 2010; 130(2):415-24

Ramadas D, Muhamed AKY, Mundasada SC. Antioxidant activity: root, leaves, and fruits aqueous extracts of Muntingia calabura. JIPBS, 2015; 2(4):363-8.

Sadowska-Bartosz I, Bartosz G. Prevention of protein glycation by natural compounds. Molecules, 2015; 20(2):3309-34.

Song X, Bao M, Li D, Li YM. Advanced glycation in D-galactose induced mouse aging model. Mech Ageing Dev, 1999; 108(3):239-51.

Sudha S, Anandh T, Ramya R. Evaluations of antioxidants and lipid peroxidation status among students. Int J Appl Biol Pharm Technol, 2012; 3(4):291-5.

Tapas AR, Sakarkar DM, Kakde RB. Flavonoids as nutraceuticals: a review. Trop J Pharm Res, 2008; 7(3):1089-99.

Tigges J, Krutmann J, Fritsche E, Haendeler J, Schaal H, Fischer JW, Kalfalah F, Reinke H, Reifenberger G, Stühler K, Ventura N, Gundermann S, Boukamp P, Boege F. The hallmarks of fibroblast ageing. Mech Ageing Dev, 2014; 138:26-44.

Varani J, Dame MK, Rittie L, Fligiel SEG, Kang S, Fisher GJ, Voorhees JJ. Decreased collagen production in chronologically aged skin: roles of age-dependent alteration in fibroblast function and defective mechanical stimulation. Am J Pathol, 2006; 168(6):1861-8.

Wang D, Liu M, Cao J, Cheng Y, Zhuo C, Xu H, Tian S, Zhang Y, Zhang J, Wang F. Effect of Colla corii asini (E'jiao) on D-galactose induced aging mice. Biol Pharm Bull, 2012; 35(12):2128-32.

Waqas MK, Akhtar N, Rasul A, Rashid SU, Mustafa R, Khan BA, Murtaza G. In vivo evaluation of a cosmetic emulsion containing soybean extract for anti-aging. Trop J Pharm Res, 2014; 13(9):1401-6. 
Yang YC, Lin HY, Su KY, Chen CH, Yu YL, Lin CC, Yu SL, Yan HY, Su KJ, Chen YL. Rutin, a flavonoid that is a main component of Saussurea involucrata, attenuates the senescence effect in D-galactose aging mouse model. Evid Based Complement Alternat Med, 2012; 2012:980276; doi:10.1155/2012/980276

Ye Y, Jia R, Tang L, Chen F. In vivo antioxidant and anti-skinaging activities of ethyl acetate extraction from Idesia polycarpa defatted fruit residue in aging mice induced by D-galactose. Evid Based Complement Alternat Med, 2014; 2014(1):185716; doi:10.1155/2014/185716

Zakaria ZA, Fatimah CA, Mat Jais AM, Zaiton H, Henie EFP, Sulaiman MR, Somchit MN, Thenamutha M, Kasthuri D. The in vitro antibacterial activity of Muntingia calabura extracts. Int J Pharmacol, 2006; 2(4):439-42.

Zakaria ZA, Hazalin NA, Mohd-Zaid SNH, Abdul Ghani M, Hassan MH, Gopalan HK, Sulaiman MR. Antinociceptive, antiinflammatory and antipyretic effects of Muntingia calabura aqueous extract in animal models. J Nat Med, 2007; 61(4):443-8.

Zakaria ZA, Mohamed AM, Jamil NS, Rofiee MS, Hussain K, Sulaiman MR et al. In vitro antiproliferative and antioxidant activities of the extracts of Muntingia calabura leaves. Am J Chin Med, 2011; 39(1):183200
Zakaria ZA, Mohd Sani MH, Cheema MS, Kader AA, Kek TL, Salleh MZ. Antinociceptive activity of methanolic extract of Muntingia calabura leaves: further elucidation of the possible mechanisms. BMC Complement Altern Med, 2014; 14:63; doi:10.1186/1472-6882-14-63

Zhang S, Dong Z, Peng Z, Lu F. Anti-aging effect of adiposederived stem cells in a mouse model of skin aging induced by D-galactose. PLoS One, 2014; 9(5):e97573; doi:10.1371/journl.pone.0097573. eCollection 2014

\section{How to cite this article:}

Sulistyoningrum E, Rosmelia R, Hamid MK, Nuraini WST. Anti-aging effects of Muntingia calabura leaves extract in D-galactose-induced skin aging mouse model. J Appl Pharm Sci, 2019; 9(09):023-029. 